\title{
How do the foreign direct investments flow? The case of the cross-border M\&As in the European Union
}

\author{
George Marian Aevoae ${ }^{\mathrm{a} 1}$, Roxana Dicu ${ }^{\mathrm{a}}$ and Daniela Mardiros ${ }^{\mathrm{a}}$ \\ a "Alexandru Ioan Cuza" University of Iasi, Romania
}

\begin{abstract}
Mergers and acquisitions (M\&As) have been a popular strategy for firms and represent an important alternative for strategic expansion. At European Union (EU) level there are companies which choose this strategic option in order to expand their activity overboard, by merging or acquiring a company from EU or from a country outside the Union. The purpose of this paper is to present a quantitative analysis, for the 2005-2016 period of time, of the cross-border mergers and acquisitions (CBM\&As) in the EU, by considering the mergers and the acquisitions of a controlling interest (100\%), taking into account only the companies that developed their activity in the EU. The paper will follow two directions. On a side, we will analyze the number and the volume of the CBM\&As for the EU member states, which will be categorized as developed, advanced emerging, secondary emerging and frontier economies, according to FTSE Russell criteria. On the other side, we will discuss the volume of the inward and outward foreign direct investments (FDI) related to CBM\&As for these countries, to confirm that the most of these funds are flowing between developed economies. The flows are correlated to the merger waves in the Europe, according to the data provided by the Institute of Mergers, Acquisitions and Alliances (IMAA) in 2018.
\end{abstract}

Keywords: cross-border mergers and acquisitions; developed, emerging and frontier economies; foreign direct investments; Lucas' paradox

JEL codes: G34, M16, M21

${ }^{1}$ Corresponding author: Department of Accounting, Business Information Systems and Statistics, "Alexandru Ioan Cuza" University of Iasi, Romania; Carol I Blvd no. 22; tel. +40752774447; e-mail address: aevoae@gmail.com 


\section{Introduction}

Mergers and acquisitions (M\&As) are seen worldwide as business transformation mechanisms which allow the involved entities the diversification or the expansion of their activities. However, these processes of ownership change and corporate value transformation are based on expectations regarding an increase of the future economic benefits for the entities, known as synergistic effects. The development of this processes led to their expansion outside the frontiers of the countries, with the title of cross-border merger and acquisitions (CBM\&As). The raise of the CBM\&As appeared after the development of national merger markets, because it allowed worldwide access to human capital competences, a better circulation of information for the stakeholders, more complex regulatory frameworks, and a better public perception on M\&As as managerial strategic tools. The cross-border deals are more complex than the domestic ones and we noticed there are studies on the differences between countries in terms of how these transactions are regulated and used (FeitoRuiz \& Menéndez-Requejo, 2011; Martynova \& Renneboog, 2008; Martynova \& Renneboog, 2011; Višić \& Škrabić Perić, 2011).

Companies access foreign markets as a result of their growth strategies, through greenfield investments, brownfield investments and CBM\&As, known, as a total, under the well-known name of foreign direct investments (FDI). In this paper, we aim to demonstrate that the FDI flow mainly between developed economies, despite the fact that the economic theory states that the emerging markets could be better choices in terms of costs and levels of return on factors of production.

According to Nocke and Yeaple (2007), a cross-border merger or acquisition allows a bidder to get costly access to the country-specific capabilities of the acquired firm, and the price of such a transaction is governed by demand and supply of firms in the market for corporate control. In contrast, by engaging in greenfield FDI, a firm brings only its own capabilities to work abroad. Thus, choosing between the two main forms is a decision of the company itself, but there are studies that conclude, based on empirical evidence, that more companies choose greenfield FDI over M\&A when investing on foreign markets (Stepanok, 2015; UNCTAD, 2018). Blonigen and Piger (2014) stated that, when deciding to develop FDI activity, the companies rely mainly on factors like trade agreements, relative labour endowments and cultural distance factors. On the same idea, Hennart and Reddy (1997) consider that these activities are based on the relevance of resource-accessing alliance formations.

Nevertheless, the flows of capital, technology, knowledge and skills across national boundaries through FDI can have both substantial positive effects of the economic development of the involved economies, especially host countries (Dike, 2018; Girma et al., 2015; Wang, 2009) and negative consequences, especially in the case of acquirers from developed economies who crowd out domestic entrepreneurs from 
least developed economies (Danakol et al., 2017). On the same page, FDI can have direct and indirect consequences, the latter being known as the "spillovers", which can appear in productivity (Javorcik, 2004), on workers (Agrawal \& Tambe, 2016; Fosfuri et al., 2001) or on the shared knowledge (Fu, 2012; Wang, 2009).

The reminder of this paper is structured as follows: Section 2 presents a theoretical delimitation between CBM\&As and greenfield investment, with an emphasis on the factors of influence. Section 3 of the paper details the aforementioned concepts in terms of figures and numbers. Section 4 discusses the main concepts and theories related to the circulation of capital between different types of economies. Section 5 presents the data used to describe the FDI situation in the European Union and to demonstrate Lucas' paradox, while Section 6 is dedicated to the results of the research. The last part of the paper is dedicated to the main conclusions of our study.

\section{CBM\&As vs. greenfield investments: alternatives for FDI in world economies}

In nowadays, globalization is an adjective we add to everything: markets, institutions, risks, finances, communications, etc. Actually, mostly from an economic point of view, this process fades the borders of the nations, allowing the interconnection of the economies. Usually, it is defined as the process by which geographical distance becomes an ever less important factor in the establishment and development of cross-border economic, political and socio-cultural relations (Bari, 2005: 30).

As a global finance tool, a FDI represents a long-term investment relationship between a resident and a non-resident entity; it usually involves a significant degree of influence exerted by the investor on the management of the direct investment enterprise in which he has invested. According to the United Nations Conference on Trade and Development (UNCTAD), a company can undertake FDI in two ways: greenfield investment in new assets (this is known as the situation where a company builds its operations in a foreign country from the ground up) or acquiring / merging with an existing local company (UNCTAD, 2000: 99, Calderón et al., 2004), the latter being either private or state owned. Thus, the link between FDI and CBM\&As is the fact that privatizations involving foreign investors count as CBM\&As. In the conference's yearly World Investment Report, information related to specific topics is presented, including CBM\&As, which were the theme of the report in 2000 (UNCTAD, 2000). In contrast to domestic M\&As, CBM\&As imply that the bidder company applies a growth strategy oriented towards foreign markets, sensing business opportunities that domestic enterprises have not yet perceived or have lacked the ability to exploit (Ahammad et al., 2017; Boateng et al., 2008). 
The choice for CBM\&As is one related to a number of factors that are influencing it. Obviously, when considering such factors, one should keep in mind that their range goes from firm-level to national-level, because the experience of the company is as important as country risks (Neto et al., 2009). Our own projection related to factors influencing the choice for CBM\&As is reflected in Figure 1.

\section{Figure 1 Factors which influence CBM\&As}

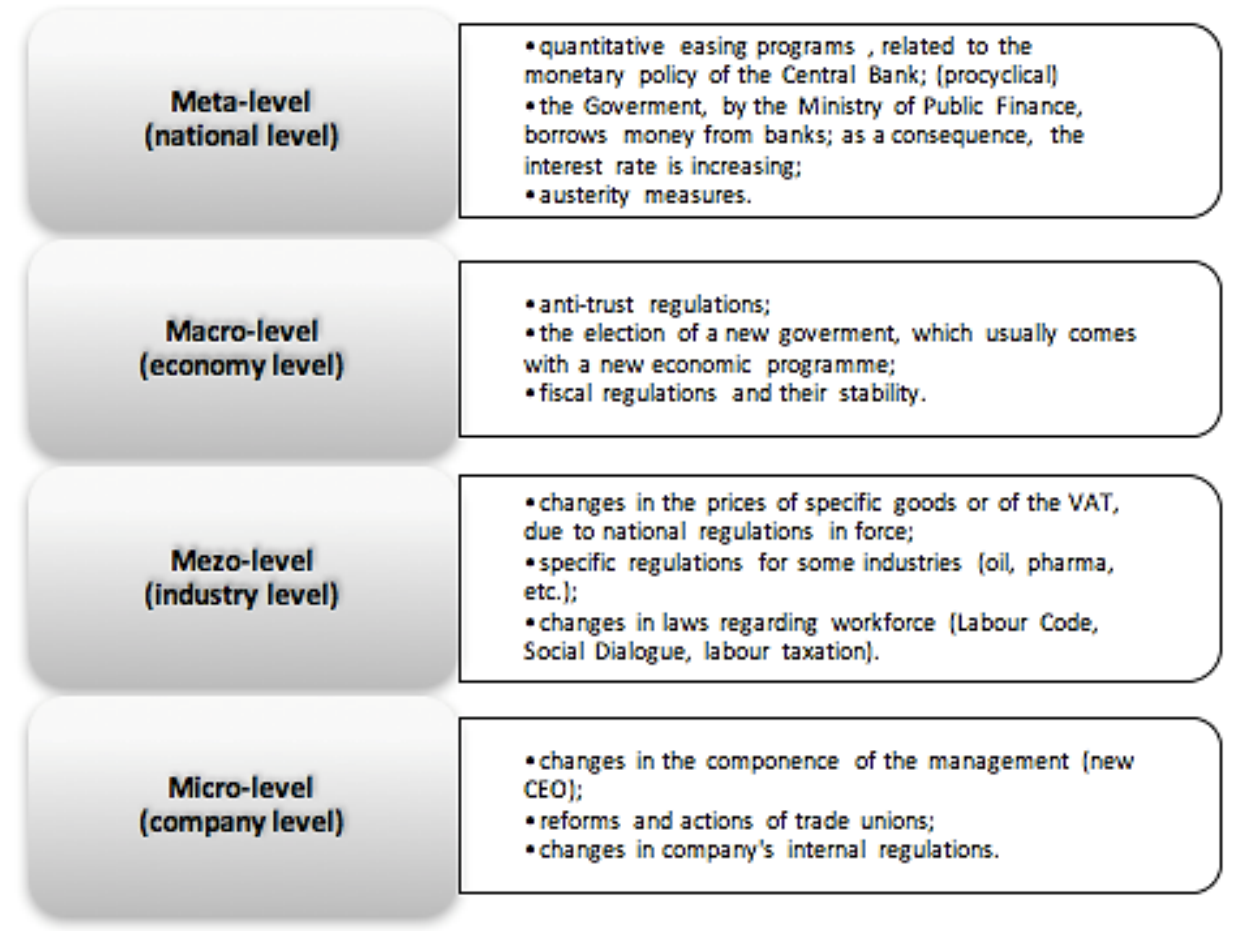

Source: Own processing after Whitaker (2016: 24)

The quantitative easing programs are procyclical, their purpose being to decrease the interest rate by creating money in the banking system. Actually, the Central banks are buying bonds from the banks and, through the infusion of money, the interest rates fall, loans are cheaper, and population is able to spend more. As a consequence, both the investments and the consumption increase. From an acquirer's point of view, a situation like this could be considered as beneficial for the CBM\&As, because, in such economies, the population is willing to spend. The opposite situation, the anticyclical one, is related to the internal public debt and its impact on the interest rate. The latter is increasing, thus limiting the access of companies and population to loans. Regarding the elections and their impact on these transactions, it is recommended that the CBM\&As take place a year before these events. This way, the companies are prepared to cope easier with potential domestic laws or regulatory changes. The regulatory changes which can appear as a result of a new Government 
appointment can increase or decrease the trust of the investors in the economy, according to the political programme they propose. At a green-level (industry level), there can be changes that affect a specific industry (a lower VAT for food or books, like the case of Romania (Fiscal Code, 2015: art. 291), the clawback tax for pharma industry, etc.) or changes in the laws regarding workforce (the minimum wage, social insurance, unemployment, etc.). For the involved companies, the changes in management or in employees' organization can have an important influence in the decision of participating in a CBM\&A. All these factors influence, on a higher or a lower level, the management's decision to involve in M\&As.

The same level perspective we found at Shimizu et al. (2004). They consider that the choice of CBM\&As as a tool for strategic expansion is often influenced by (1) firmlevel factors such as multinational experience, local experience, product diversity, internal isomorphism, and international strategy; (2) industry-level factors such as technological intensity, advertising intensity, and sales force intensity; and (3) country-level factors such as market growth in the host country, cultural idiosyncrasies between the home and host countries, and the specific culture of the acquiring firm's home country (particularly in terms of uncertainty avoidance and risk propensity).

By surveying a large number of journal articles, Xie et al. (2017) classify, summarize and integrate various cross-country determinants for M\&As into seven major taxonomies: macroeconomic and financial markets environment, institutional and regulatory framework, political environment and corruption, tax and taxation laws, accounting standards, geographical factors, and cultural issues.

\section{FDI and CBM\&As at a global level}

United Nations Conference on Trade and Development (UNCTAD) is the main UN body dealing with trade, investment and development issues. Since 1991, it has been presenting, yearly, a World Investment Report, which can be described as a timely contribution to both an important debate and an image of the international investment and development community. A consistent part of their yearly report consists of the situation of the FDI in and out of developed, developing and transition economies (according to UNCTAD country classification), which allows us a historical perspective on these flows.

According to UNCTAD, in 2013, the outstanding funds of private equity firms increased to a record level of more than 1 trillion $\$$. Their cross-border investment was 171 billion \$, recording a decline of $11 \%$, and they accounted for $21 \%$ of the value of CMB\&As. With funds available for investment, and relatively subdued activity in recent years, the potential for increased private equity FDI was significant (UNCTAD, 2014). When mentioning this, we have to keep in mind that the low level 
of flows to developed countries persisted in 2014, compared to 2013. Despite a revival in CBM\&As, overall FDI flows to this group of economies declined by $28 \%$ to 499 billion $\$$. They were significantly affected by a single large-scale disinvestment from the United States (UNCTAD, 2015). But the recovery in FDI was strong in 2015 . Global foreign direct investment flows jumped by $38 \%$ to 1,76 trillion \$, their highest level since the global economic and financial crisis of 2008-2009. A surge in CBM\&As to 721 billion \$, from 432 billion $\$$ in 2014, was the principal factor behind the global rebound. The value of announced greenfield investment remained at a high level, at 766 billion \$ (UNCTAD, 2016). For the 2016-2017 period of time, the values of FDI inflows and outflows are presented in Table 1.

Table 1. The value of FDI inflows and outflows, in 2016-2017 period of time

\begin{tabular}{lrrrr}
\hline \multicolumn{1}{c}{ Region } & \multicolumn{2}{c}{ FDI inflows (billions \$) } & \multicolumn{2}{c}{ FDI outflows (billions \$) } \\
& $\mathbf{2 0 1 6}$ & $\mathbf{2 0 1 7}$ & $\mathbf{2 0 1 6}$ & \multicolumn{2}{c|}{$\mathbf{2 0 1 7}$} \\
\hline Total & 1.868 & 1.430 & 1.461 & 1.421 \\
Developed economies, & 1.133 & 712 & 1.031 & 1.000 \\
out of which: & & & & \\
Europe & 565 & 334 & 529 & 418 \\
Developing economies & 670 & 671 & 405 & 381 \\
Transition economies & 64 & 47 & 25 & 40 \\
\hline
\end{tabular}

(Source: Own processing after UNCTAD (2018), World Investment Report. Investment and New Investment Policies, United Nations, New York and Geneva, 2018, available online at http://unctad.org/en/PublicationsLibrary/wir2018_en.pdf)

Given the fact that CBM\&As and the greenfield project are the main components of the FDI, they will be presented in the following tables. For the 2016-2017 period of time, the values of CBM\&As are presented in Table 2.

Table 2. The value and number of CBM\&As in 2016-2017 period of time

\begin{tabular}{lrrrr}
\hline \multicolumn{1}{c}{ Industry } & CBM\&As (value - billions of \$) & \multicolumn{2}{c}{ CBM\&As (number) } \\
& $\mathbf{2 0 1 6}$ & $\mathbf{2 0 1 7}$ & $\mathbf{2 0 1 6}$ & $\mathbf{2 0 1 7}$ \\
\hline Total & 887 & 694 & 6.607 & 6.967 \\
Primary & 83 & 24 & 206 & 550 \\
Manufacturing & 406 & 327 & 1.745 & 1.690 \\
Services & 398 & 343 & 4.656 & 4.727 \\
\hline
\end{tabular}

(Source: UNCTAD (2018), World Investment Report. Investment and New Investment Policies, United Nations, New York and Geneva, 2018, page 8, available online at http://unctad.org/en/PublicationsLibrary/wir2018_en.pdf)

For the 2016-2017 period of time, the values of the greenfield investments are presented in Table 3. 
How do the Foreign direct investments flow?

The case of the cross-border M\&As in the European Union

Table 3. The value and number of greenfield investments in 2016-2017 period of time

\begin{tabular}{|c|c|c|c|c|}
\hline \multirow{2}{*}{ Industry } & \multicolumn{2}{|c|}{$\begin{array}{c}\text { Greenfield projects (value - } \\
\text { billions of \$) }\end{array}$} & \multicolumn{2}{|c|}{ Greenfield projects (number) } \\
\hline & 2016 & 2017 & 2016 & 2017 \\
\hline Total & 833 & 720 & 15.766 & 15.927 \\
\hline Primary & 54 & 21 & 52 & 63 \\
\hline Manufacturing & 295 & 338 & 7.703 & 7.678 \\
\hline Services & 484 & 362 & 8.011 & 8.186 \\
\hline
\end{tabular}

(Source: UNCTAD (2018), World Investment Report. Investment and New Investment Policies, United Nations, New York and Geneva, 2018, page 8, available online at http://unctad.org/en/PublicationsLibrary/wir2018_en.pdf)

Global FDI flows fell 13\% in 2016, reaching an estimated 1.52 trillion \$, in a context of weak global economic growth and a lackluster increase in the volume of world trade (UNCTAD, 2017). The decrease continued in 2017 , by $23 \%$, to 1,43 trillion $\$$, in stark contrast to the accelerated growth in GDP and trade. The fall was determined, partly, in the value of the M\&As. In 2017, although the number of CBM\&As increased from 6.607 in 2016 to 6.967 , their value dropped to 694 billion $\$$, representing a decrease of $21,76 \%$ (Table 2). Equity investments at the global level were boosted by a $13 \%$ increase in the value of CBM\&As, which rose to their highest level since 2007, reaching 887 billion $\$$. The value of greenfield projects announcements reached an estimated 833 billion $\$-$ a $5 \%$ rise from the previous year, although this was largely due to several very large projects announced in a handful of countries (UNCTAD, 2018; World Bank, 2017).

CBM\&As constitute a large share of FDI flows, reaching, in the years of merger waves, their higher peak of $80 \%$ of the total, given the fact that target firms can benefit from the acquisition or merger of a foreign company (Stiebale \& Reize, 2011). In other words, foreign investments help companies overcome constraints like: (1) difficult and adverse funding sources, (2) outdated technology and business organization, (3) saturated and/or insufficient domestic market, (4) a slow adjustment to market conditions etc. (Višić \& Škrabić Perić, 2011:174).

\section{The circulation of capital between developed and emerging economies}

When discussing CBM\&As, another focal point, which complements the FDI approach, is related to the circulation of capital. Brouthers and Dikova (2010) analyzed a sample of Western Europe companies which entered the Eastern Europe market, arguing that greenfield investments are a better option than acquisitions. The benefits of the CBAs between companies located in developed economies (as acquirers) and the ones from emerging markets (as targets) were also noticed by Bednarczyk et al. (2010) and Chari et al. (2010). Rabbiosi et al. (2012) argue that the companies from emerging economies build an organizational learning 
perspective if they enter developed economies markets, by closing transactions as CBM\&As. Lebedev et al. (2015) studied the M\&As in and out of the emerging economies and consider that the main focus when comparing the CBM\&As between markets is on antecedents (motivation) and outcomes (performance). Erel et al. (2012) analyzed a sample of 56.978 CBM\&As closed by USA companies, arguing that companies from countries with appreciated currencies, increased stock market value, and quality of disclosures requested by law tend to be acquirers of target from weaker-performing economies.

As the empirical evidence underlines, a major difference appears between developed and emerging economies. The standard neoclassical theory predicts that when two countries produce the same good with the same constant returns to scale production function, then the law of diminishing returns dictates that the marginal product of capital is higher in the less productive economy (Lucas, 1990; Višić \& Škrabić Perić, 2011). The law of diminishing returns states that, by increasing one factor of production, while the others remain constant (caeteris paribus), inevitably the return per product decreases. Thus, the capital should flow from developed economies to the emerging ones. But funds go to the most advanced economies. This is known as Lucas paradox (Lucas, 1990). The explanations are multiple, but the firsts that come to mind are those related to antagonistic relation between higher returns on capital, on a side, and the laws, the economic performance and the quality of the institutions, specific to emerging and frontier economies, on the other side. In other words, the criteria which don't allow an economy to be classified as developed are the ones that stand in the way of progress, in our case in the way of developing commercial deals as CBM\&As.

Regarding the transactions between developed economies, although they seem comparable in terms of laws and quality of institutions, they do vary in terms of regulations, and those referring to CBM\&As are not an exception. The differences are subtle and related to banking and their relation to companies, the circulation of information between stakeholders, the treatment of human resources, the way corporate growth strategies are supported by the government, etc. Likewise, a focus point regarding CBM\&As regulations is related to the perception of the owners of the entities involved in the process on the fact that they should pay attention to the ones from the other countries and not continuing the deal on the assumption that the home regulations are replicated worldwide ("principle of caution") (Whitaker, 2016).

\section{Research design and methodology}

Through an empirical, descriptive research, we will study the CBM\&As in which the countries of the European Union were involved, for the 2005-2016 period of time, aiming at identifying and presenting the characteristics of the studied 
phenomenon. The data regarding M\&As were collected from the Zephyr database. One important characteristic of the dataset is that it covers a large fraction of companies, across all industries. Further, it provides information on both listed and unlisted companies. This feature of the data allows for a wide degree of observations in our sample. The search strategy took into consideration the deal status (completedassumed, completed-confirmed, rumored, announced), the deal type (merger, acquisition), the geography criterion (European Union enlarged - 28 countries, as acquirer or target or vendor), for 2005-2016 period of time. As a result of the search, a number of 8.105 transactions were generated.

The transactions with other deal status than "completed-assumed" and "completed" were eliminated (3.160 transactions). The transactions that were eliminated and their status are presented in Table 4.

Table 4. The eliminated transactions from the zephyr database

\begin{tabular}{cc}
\hline Name & Total \\
\hline Total deals & $\mathbf{8 . 1 0 5}$ \\
(-) Announced & 106 \\
(-) Pending & 20 \\
(-) Pending awaiting regulatory for approval & 42 \\
(-) Pending shareholder & 2 \\
(-) Postponed & 8 \\
(-) Rumor & 453 \\
(-) Rumor analyst speculation & 78 \\
(-) Rumor expired & 1.674 \\
(-) Rumor informal offer/non-binding & 27 \\
(-) Rumor withdrawn & 245 \\
(-) Withdrawn & 505 \\
Completed, out of which: & $\mathbf{4 . 9 4 5}$ \\
- completed & 4.290 \\
- completed assumed & 655 \\
\hline
\end{tabular}

(Source: Zephyr database 2005-2016 (Bureau Van Dijk))

To obtain our sample, which consists of the transactions representing mergers and acquisitions of a controlling interest (100\%), we eliminate as follows:

1. the domestic M\&As and CBM\&As that involved a target and an acquiring company from outside of the European Union (641 transactions). These transactions were included in the database because the vendor of the securities was from the European Union, but they are of no interest for our study;

2. the transactions from 2017 (123 transactions), because the year is not completed, and our research takes into account the 2005-2016 period of time;

3. the domestic M\&As, because the focal point of our study is to analyze the CBM\&As (1.326 transactions); 
4. the acquisitions which represent investments in associated entities (3 transactions) and investments in jointly controlled entities (1 transaction);

5. the transactions between more than two entities and we keep only transactions $1: 1$, mergers and acquisitions of a controlling interest of $100 \%$ (1.362 transactions).

The cross-border mergers and acquisitions of a controlling interest of 100\% which are to be analyzed are in number of 1.489. The mergers and the acquisitions in percentage of $100 \%$ were applying the provisions of the Regulation no. 139/2004 on the control of concentrations between undertakings and are presented on the European Commission website (European Commission, 2017).

For the data collection, we use the observation method, considered useful to highlight the characteristics of the participating companies and understand the motivations behind the M\&As.

As a result, in the quantitative part of the paper, we will present: the FDI situation at country level, as inflows (the target company has the residence in an EU country) and outflows (the acquiring company with the appurtenance in an EU country), on a side, and geographical area (Western and Eastern Europe), on the other side. This information will be correlated with the merger waves in Western and Eastern Europe. Given the fact that the quantitative study is referring to the 2005-2016 period of time, we will group the years according to the merger waves in Western Europe (using the value criterion): 2004-2009 (the third wave), 2010-2014 (the fourth wave), 20152016 (the fifth wave) and Eastern Europe: 2004-2013 (third wave), 2014-2016 (the fourth wave) (IMAA, 2018). Also, we want to demonstrate Lucas' paradox, taking into account the transactions between EU countries, grouped according to the FTSE Russell criteria into Not indexed, Frontier, Secondary Emerging, Advanced Emerging, Developed.

\section{The results of the research}

The approach of CBM\&As is better made in terms of inflows and outflows, because these strategic transactions are a part of the foreign direct investments. In Figure 2 we can notice the evolution of the outflows from EU countries. Considering the years 2006, 2011, 2015, the peaks of the merger weaves we find appropriate presenting the countries and the value of the transactions with community dimension in the mentioned years. 


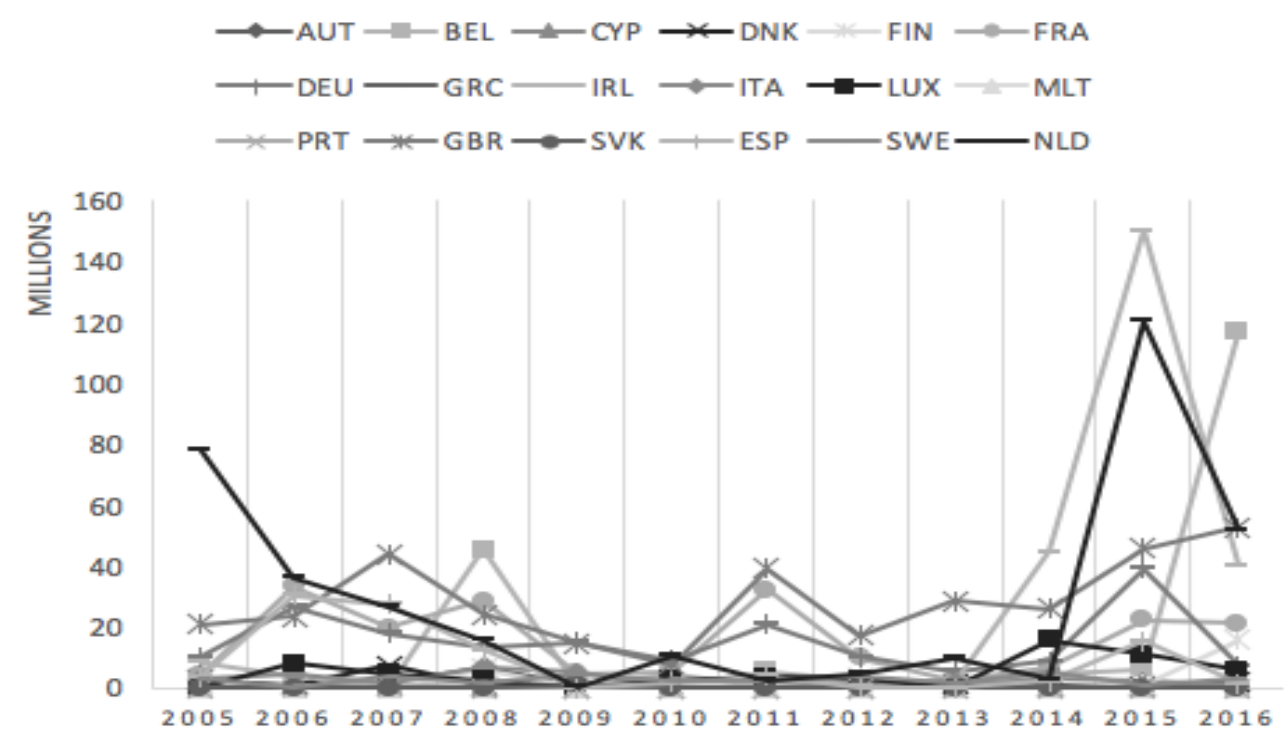

Figure 2. The outflows of FDI from EU countries (Western Europe)

Thus in 2006 the most significant registered value belongs to Netherlands (NDL) with the amount of 36.017 million dollars. In 2011 we find GBR and the amount was 39.077 million dollars and in the year of 2015 the country which registered the biggest outflow value of FDI representing CBM\&As was Ireland (IRL), with a value of 149.970 million dollars. The results are consistent with total values for Western EU CMB\&As transactions, which registered the top values in the same years mentioned above (2006 - 169.952 mil dollars, 2011 - 112.564 mil dollars, 2015 414.701 mil dollars).

The inflows of the FDI from CBM\&As in the Western Europe, represented in Figure 3 , follow the same trend as the outflows. In this case, we also notice that Netherlands registers the best trend for the inflows of FDI, and the total values for the 2005-2016 period of time also registered their picks in the years 2006 (149.363 mil dollars), 2011 (103.685 mil dollars) and 2015 (311.373 mil dollars). 


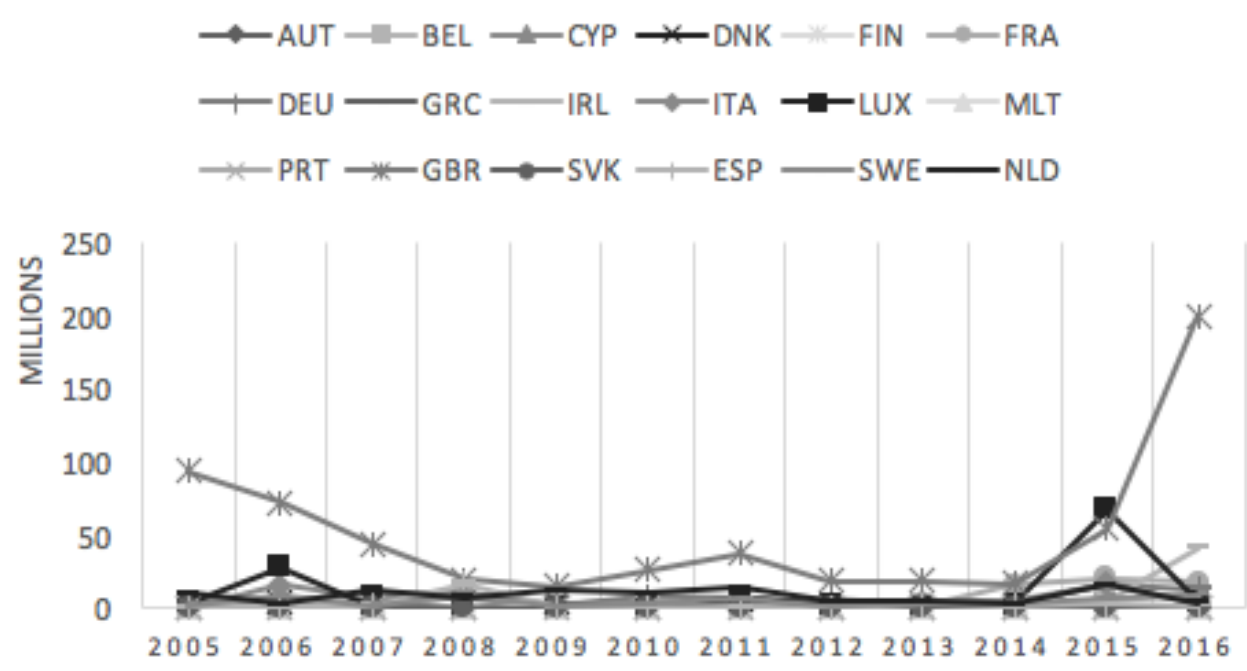

Figure 3. The inflows of FDI in EU countries (Western Europe)

In the case of Eastern Europe, the things are different, because the merger waves followed a different trend as the Western Europe (2004-2013 and 2014-2016, for the considered period). Given the fact that there were few transactions with community dimension for the Eastern Europe, it is difficult to consider a trend. The values for each country are represented in Figure 4. For Eastern Europe, the values are represented in thousands of dollars compared to Western Europe where they are presented in millions of dollars. We decide this due to the fact that the values of the FDIs in Eastern Europe are showing a lower level compared to the opposite side of Europe. More, it seems that the countries from the Western Europe reacted to the financial crisis. The years 2009 and 2010 are a fall in the value of the CBM\&As (outflows 2009 - 47.121 mil dollars; outflows 2010 - 45.711 mil dollars; inflows $2009-48.775$ mil dollars; inflows $2010-62.619$ mil dollars). We cannot draw such a conclusion referring to the Eastern Europe. 
How do the Foreign direct investments flow?

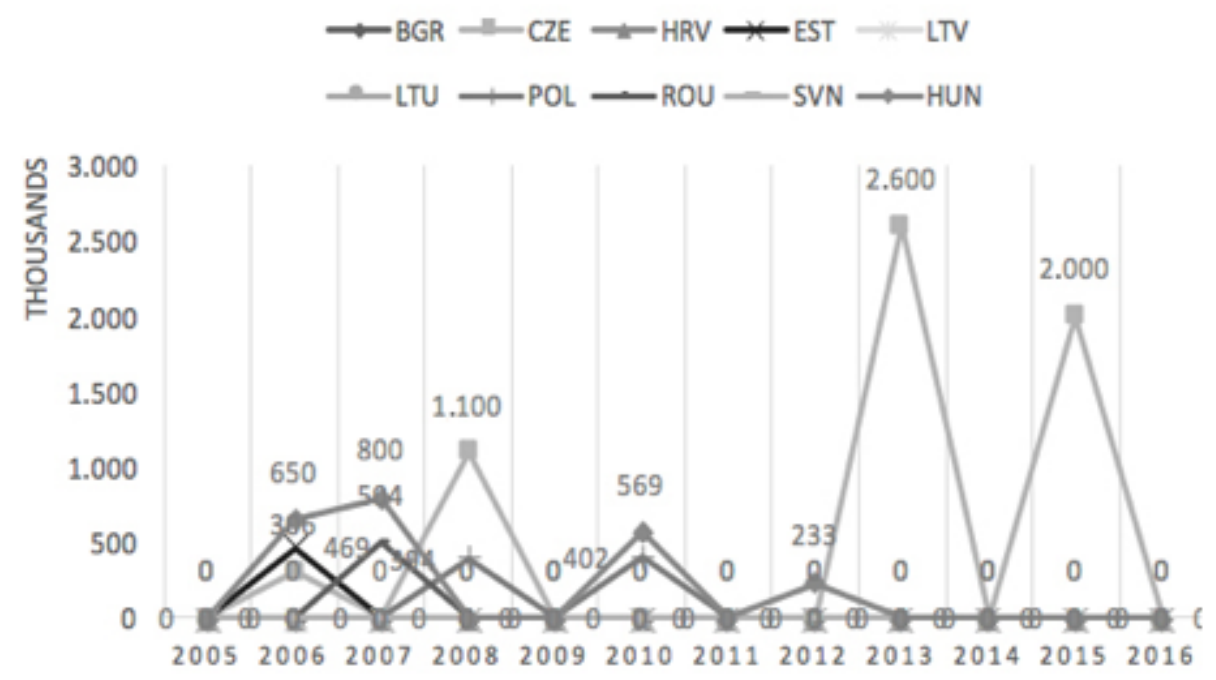

Figure 4. The outflows of FDI from EU countries (Eastern Europe)

For the inflows of FDI in the countries from Eastern Europe (the target companies are located in these countries), the values are displayed in Figure 5.

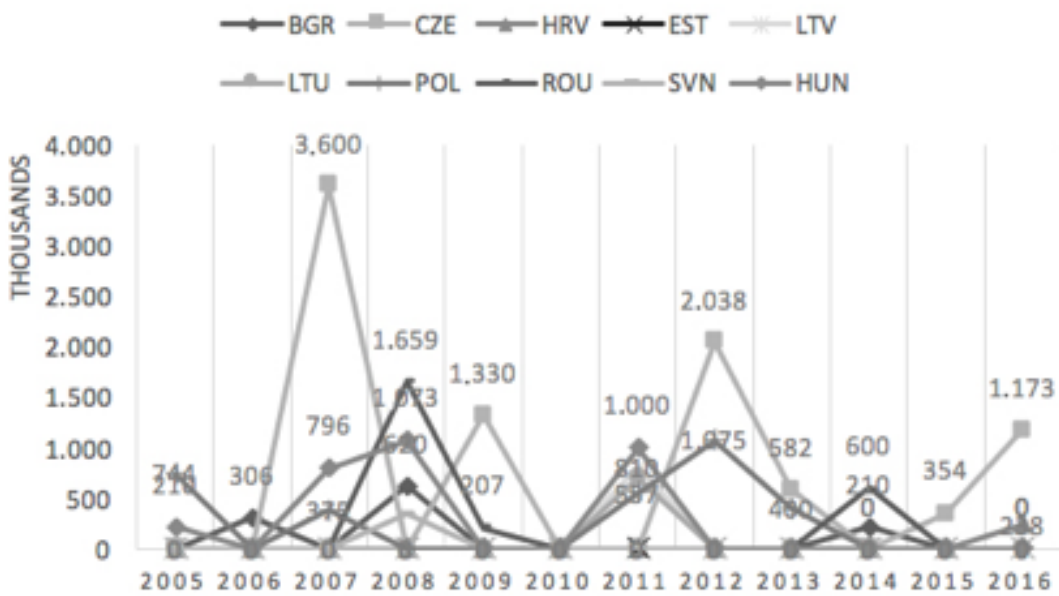

Figure 5. The inflows of FDI in EU countries (Eastern Europe) 
In Table 5 we present the total values of inflows and outflows of the countries from the European Union enlarged, for the 2005-2016 period of time, taking into account all the mergers and acquisitions of a controlling interest (100\%). As noticed in Table 5 and Figure 6, Netherlands presents the best situation of outflows of FDI (considering all the transactions in which a Dutch acquiring company was involved, the host country of the target being from anywhere in the world -19,84\%) and the United Kingdom for the inflows of FDI (the situation when British companies where in the position of target $-34,36 \%$ ). Since the second position for the outflow FDI also belongs to United Kingdom, this speaks volumes about the financial power of this country in the European Union, before activating the article 50 from the Lisbon Treaty on March 29, 2017, in order to leave the EU at 11 pm (2300 GMT), on the same day in 2019 (Reuters, 2018). At the other end of the spectrum, we find Bulgaria (BGR), Croatia (HRV), Lithuania (LTU), Latvia (LTV) and Slovenia (SVN), all of them belonging to Eastern Europe, with 0 investments with community dimension from their companies, as acquirers. If we consider the inflows of FDI, we didn't find investments in Estonia, also an Eastern European country.

Table 5. The inflows and outflows of FDI - European Union enlarged -thousand dollars-

\begin{tabular}{|c|c|c|c|c|c|}
\hline \multirow[b]{3}{*}{ Indicator } & \multirow{2}{*}{\multicolumn{5}{|c|}{ Country Code }} \\
\hline & & & & & \\
\hline & AUT & BEL & BGR & CYP & CZE \\
\hline FDI outflows & 13.121 .177 & 182.849 .692 & 0 & 8.440 .750 & 6.006 .000 \\
\hline$\%$ total & $0.73 \%$ & $10.12 \%$ & $0 \%$ & $0.47 \%$ & $0.33 \%$ \\
\hline FDI inflows & 14.169 .188 & 32.082 .019 & 1.136 .458 & 5.310 .825 & 9.076 .782 \\
\hline$\%$ total & $0.78 \%$ & $1.78 \%$ & $0.06 \%$ & $0.29 \%$ & $0.50 \%$ \\
\hline Indicator & DEU & DNK & ESP & EST & FIN \\
\hline FDI outflows & 183.405 .641 & 15.813 .019 & 98.074 .489 & 468.850 & 29.076 .052 \\
\hline$\%$ total & $10.15 \%$ & $0.87 \%$ & $5.43 \%$ & $0.03 \%$ & $1.61 \%$ \\
\hline FDI inflows & 91.078 .359 & 19.239 .879 & 35.605 .075 & 0 & 14.074 .458 \\
\hline$\%$ total & $5.04 \%$ & $1.06 \%$ & $1.97 \%$ & $0 \%$ & $0.78 \%$ \\
\hline Indicator & FRA & GBR & GRC & HRV & HUN \\
\hline FDI outflows & 190.889 .180 & 343.049 .485 & 706.439 & 0 & 2.252 .040 \\
\hline$\%$ total & $10.56 \%$ & $18.98 \%$ & $0.04 \%$ & $0 \%$ & $0.12 \%$ \\
\hline FDI inflows & 93.489 .669 & 620.985 .717 & 5.749 .608 & 237.500 & 3.078 .765 \\
\hline$\%$ total & $5.17 \%$ & $34.36 \%$ & $0.32 \%$ & $0.01 \%$ & $0.17 \%$ \\
\hline Indicator & IRL & ITA & LTU & LTV & LUX \\
\hline FDI outflows & 257.190 .021 & 26.430 .040 & 0 & 0 & 56.696 .452 \\
\hline$\%$ total & $14.23 \%$ & $1.46 \%$ & $0 \%$ & $0 \%$ & $3.14 \%$ \\
\hline FDI inflows & 72.743 .546 & 77.580 .948 & 701.000 & 810.000 & 123.767 .848 \\
\hline$\%$ total & $4.02 \%$ & $4.29 \%$ & $0.04 \%$ & $0.04 \%$ & $6.85 \%$ \\
\hline
\end{tabular}


How do the Foreign direct investments flow?

The case of the cross-border M\&As in the European Union

\begin{tabular}{cccccc}
\hline Indicator & MLT & NLD & POL & PRT & ROU \\
FDI outflows & 0 & 358.556 .482 & 796.877 & 883.200 & 504.380 \\
\% total & $0 \%$ & $19.84 \%$ & $0.04 \%$ & $0.05 \%$ & $0.03 \%$ \\
FDI inflows & 1.366 .285 & 106.017 .717 & 3.151 .138 & 3.265 .197 & 2.465 .700 \\
\% total & $0.08 \%$ & $5.87 \%$ & $0.17 \%$ & $0.18 \%$ & $0.14 \%$ \\
Indicator & SVK & SVN & SWE & & \\
FDI outflows & 881.567 & 0 & 31.283 .082 & & \\
\% total & $0.05 \%$ & $0 \%$ & $1.73 \%$ & & \\
FDI inflows & 266.670 & 350.000 & 59.066 .181 & & \\
\% total & $0.01 \%$ & $0.02 \%$ & $3.27 \%$ & & \\
Indicator & Total & & & \\
FDI outflows & $1.807 .374 .914-100 \%$ & & \\
FDI inflows & $1.396 .866 .534-100 \%$ & & \\
\hline
\end{tabular}

(Source: own processing after Zephyr database 2005-2016 (Bureau Van Dijk))

Analyzing the Figure 6, it is obvious which are the countries who had the highest inflows (United Kingdom - GBR, followed by far by Luxembourg - LUX and Netherlands - NDL) and outflows of FDI (Netherlands - NDL, followed by the United Kingdom - GBR and Ireland - IRL), considering the CBM\&As with a community dimension, in which at least one EU country was involved, as target or acquirer.

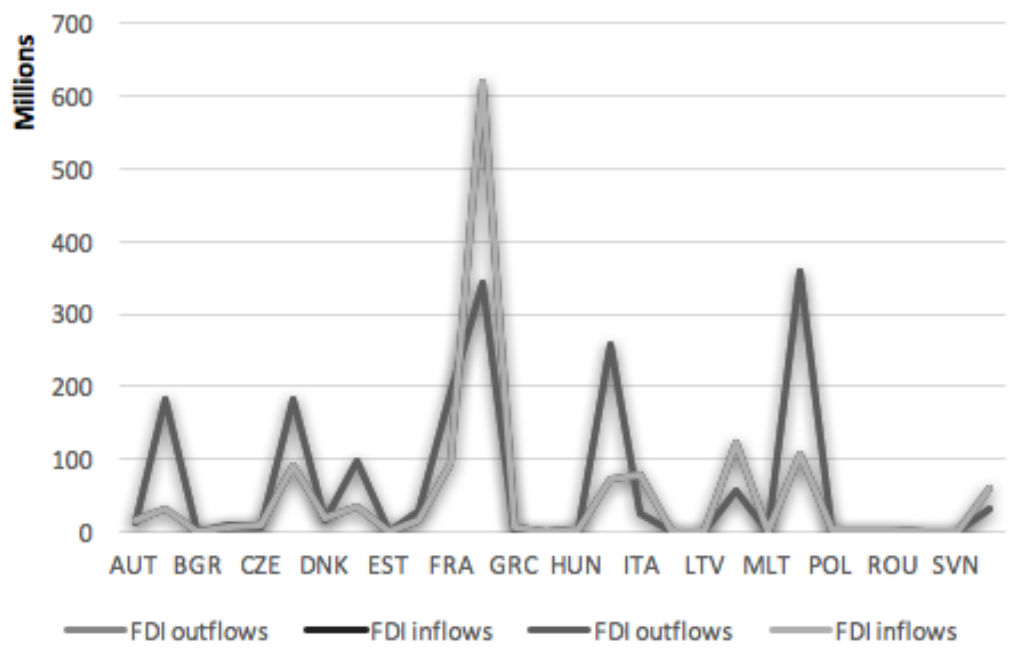

Figure 6. The total of inflows and outflows for the EU enlarged

In Figure 6, we present an analysis of the target countries from the EU, considering the statistical classification of economic activities in the European Community (NACE Rev.2) (Eurostat, 2008). 


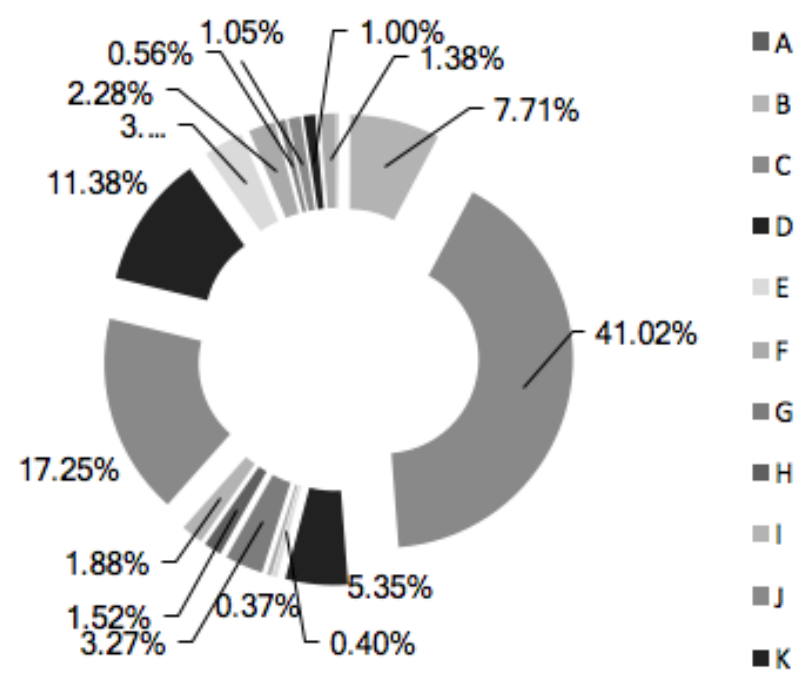

Figure 7. Distribution of target companies according to NACE Rev.2

As seen in Figure 7, the most transactions involved a target company which declared, as the main activity, one from section C Manufacturing (41,02\%), followed by J Information and communication $(17,25 \%)$ and $\mathrm{K}$ Financial and insurance activities $(11,38 \%)$.

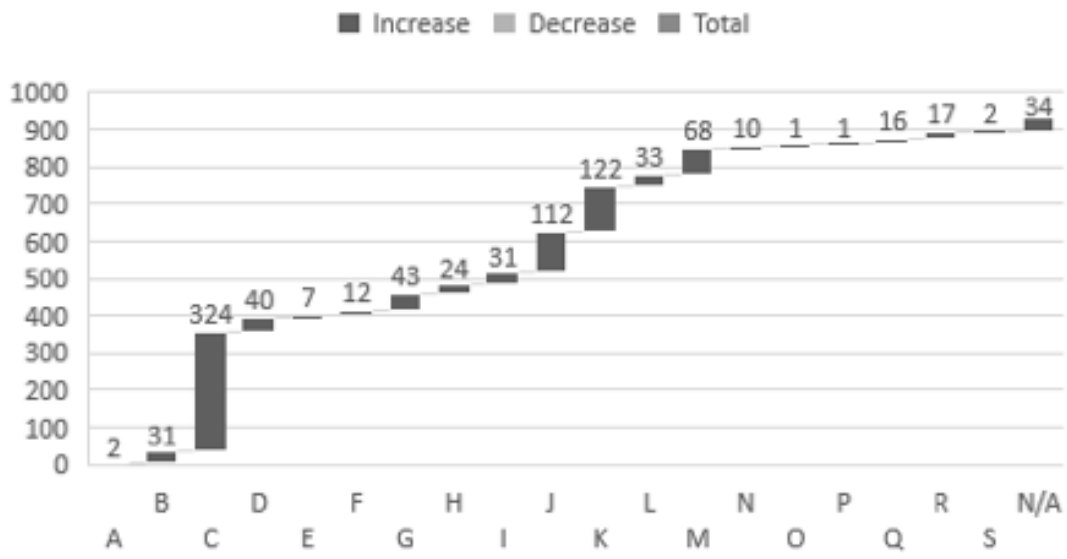

Figure 8. Number of transactions by target from the European Union 
Although the funds should flow from the developed economies to the emerging and frontier ones, as the economic theory states (as presented above), funds go to the most advanced economies. This assertion is known as Lucas' paradox, presented in the qualitative part of our paper, which we manage to demonstrate using information from the 930 transactions with community dimension, which involved exclusively countries from EU, as target or acquirer (their number is structured by NACE Rev. 2 in Figure 8). Beyond the fact that these are the most representative M\&A transactions in the EU, given the criteria which must be accomplished by a transaction to be considered having that dimension, their values help us affirm that, in the European Union, the FDI circulate, in a very large proportion, between the developed economies in the Union $(96,10 \%$, using data from Table 7$)$. To sustain this affirmation, we also present the data from Table 6 , which synthesizes the values of transactions between different types of economies, for the 2005-2016 period of time.

Table 6. The flows of FDI between types of economies for 2006-2016

\begin{tabular}{|c|c|c|c|c|c|c|}
\hline & $\begin{array}{c}\text { Type of } \\
\text { economy }\end{array}$ & NI & $\mathbf{F}$ & SE & $\mathbf{A E}$ & D \\
\hline 2006 & NI & & & & & 468.850 \\
\hline 2006 & SE & 306.000 & & & & \\
\hline 2006 & D & & & & & 98.078 .245 \\
\hline 2007 & NI & & & & & 945.553 \\
\hline 2007 & SE & & & & & 800.000 \\
\hline 2007 & D & 4.050 .000 & & 4.301 .033 & & 54.992 .624 \\
\hline 2008 & SE & & 1.100 .000 & & & \\
\hline 2008 & $\mathbf{A E}$ & & & & & 394.451 \\
\hline 2008 & D & & 1.783 .700 & & 1.072 .732 & 66.406 .194 \\
\hline 2009 & $\mathbf{F}$ & & & & & 881.567 \\
\hline 2009 & D & & 207.000 & & & 33.972 .650 \\
\hline 2010 & $\mathbf{A E}$ & & & & & 236.500 \\
\hline 2010 & D & & & & & 12.936 .556 \\
\hline 2011 & D & 810.000 & 701.000 & & 1.000 .000 & 42.320 .301 \\
\hline 2012 & D & & & & 3.113 .617 & 16.581 .520 \\
\hline 2013 & $\mathbf{A E}$ & & & & & 2.600 .000 \\
\hline 2013 & D & & & & 400.000 & 17.420 .352 \\
\hline 2014 & D & & 600.000 & & & 29.681 .627 \\
\hline 2015 & $\mathbf{F}$ & & & & & 10.263 .380 \\
\hline 2015 & $\mathbf{A E}$ & & & & & 2.000 .000 \\
\hline 2015 & D & & 66.485 .000 & & & 58.334 .042 \\
\hline 2016 & $\mathbf{F}$ & & & & & 5.799 .925 \\
\hline 2016 & D & & 3.199 .450 & & 1.173 .185 & 171.032 .069 \\
\hline Total & & 5.166 .000 & 74.076.150 & 4.301.033 & 6.759.534 & 626.146 .406 \\
\hline
\end{tabular}

(Source: own processing after Zephyr database 2005-2016 (Bureau Van Dijk))

The most significant value of transactions between developed economies appears in 2016 , representing $27,32 \%$ from the total of the transactions between this type of economies. The investments of acquirers from developed economies in companies 
located in advanced emerging economies present the highest value in 2012 (3.113.617 th dollars), in secondary emerging economies in 2007 (4.301.033 th dollars), and in frontier economies in 2015 (66.485.000 th dollars).

Cumulating the data from Table 6, we get the data from Table 7, which presents the total volume of transactions, considering the types of economies (not indexed - NI, frontier $-\mathrm{F}$, secondary emerging $-\mathrm{SE}$, advanced emerging - AE, developed - D), for the 2006-2016 period of time. Also, the Table 7 includes the percentage of presented flows in the total of 817.515.883 th dollars, representing the total of CBM\&As, which involved exclusively countries from the EU enlarged.

Table 7. The total values of transactions, by types of economies, for the period 2005-2016 (thousand dollars)

\begin{tabular}{|c|c|c|c|c|c|}
\hline \multicolumn{6}{|c|}{ TARGET } \\
\hline ACQUIRER & NI & $\mathbf{F}$ & SE & $\mathbf{A E}$ & D \\
\hline NI & & & & & $\begin{array}{r}1.414 .403 \\
0.17 \%\end{array}$ \\
\hline $\mathbf{F}$ & & & & & $\begin{array}{r}16.944 .872 \\
2.07 \%\end{array}$ \\
\hline SE & $\begin{array}{r}306.000 \\
0.04 \%\end{array}$ & $\begin{array}{r}1.100 .000 \\
0.13 \%\end{array}$ & & & $\begin{array}{r}800.000 \\
0.10 \%\end{array}$ \\
\hline $\mathbf{A E}$ & & & & & $\begin{array}{r}5.230 .951 \\
0.64 \%\end{array}$ \\
\hline D & $\begin{array}{r}4.860 .000 \\
0.59 \%\end{array}$ & $\begin{array}{r}72.976 .150 \\
8.93 \%\end{array}$ & $\begin{array}{r}4.301 .033 \\
0.53 \%\end{array}$ & $\begin{array}{r}6.759 .534 \\
0.83 \%\end{array}$ & $\begin{array}{r}601.756 .180 \\
73.61 \%\end{array}$ \\
\hline Total & 5.166 .000 & 74.076 .150 & 4.301.033 & 6.759 .534 & 626.146 .406 \\
\hline
\end{tabular}

We can see that in Table 7, at the intersection of rows and columns, we find the values, as total for the 2006-2016 period of time. We have excluded the year 2005 because, according to FTSE Russell classification, all the economies to which we refer in this paper have no classification for the mentioned year. Although there is no information available for 2005, referring to country classification, the volume of transactions for the year was up to 101.066 .760 th dollars, representing $12,36 \%$ out the total of 817.515.883 th dollars (the amount of transactions which involved only countries from EU, as target or acquiring company). The difference is 716.449.123 th dollars, split between different types of flows between economies, presented in Table 7.

\section{Conclusions}

Globalization offers enormous opportunities for economic growth and sustainable development with potential benefits on a scale difficult to imagine. As a result, FDI 
flows have recorded high values in the last years, with oscillations due to financial crisis, Brexit and other local or global events that affected the worldwide economy. In this context, developed economies attracted/invested funds from/to the countries with the same ranking. In the same time, developing countries, and least developed countries in particular, face considerable challenges. They range from structural constraints, such as the lack of adequate infrastructure and scarce access to finance, to strategic issues. In 2018, the projections for global FDI show fragile growth. Global flows are forecast to increase marginally, by up to $10 \%$, but remain well below the average over the past 10 years.

At EU level, the M\&As are considered having a strategic importance. For this purpose, the Regulation no. 139/2004 sets the rules for controlling the transactions with community dimension, in order to avoid a negative impact towards society. Our study is based on 1.489 CBM\&As, and we conclude that the developed economies from the Western Europe are involved in the most transactions, that usually the manufacturing companies are involved in M\&As (in order to control a market or to optimize their supply chain) and, at EU level exclusively, the Lucas' paradox is proved $(73,61 \%$ of the M\&As are closed between companies located in developed economies). Thus, in an environment marked by strong economic growth and elevated political risks, investors' pursuit of profitable businesses, mostly beyond the borders of their residence countries, raises the importance of FDI.

A second conclusion refers to the fact that, in our sample, only two transactions were declared as mergers $100 \%$, the rest of 1.487 are reported as acquisitions of a controlling interest (100\%). Even when mergers are supposedly between relatively equal partners, most transactions are in fact acquisitions, with one company controlling the other. The real number of mergers is so low that, for practical purposes, the acronym M\&As basically means acquisitions.

\section{Acknowledgements}

The authors acknowledge the guidance of the editor in chief of JAMIS. An earlier version of this paper was presented at the International Conference Accounting and Management Information Systems at the Bucharest University of Economic Studies, in 2018.

\section{References}

Agrawal, A. \& Tambe, P. (2016) "M\&A and Spillover Effects on Workers", Working paper, available online at http://www.research.mbs.ac.uk/ accounting-finance/Portals/0/Users/002/02/2/M\%20and\%20A\%20and\% 20Spillover\%20Effects\%20on\%20Workers.pdf [on-line access: March $17^{\text {th }}$ 2018] 
Ahammad, M., Tarba, S., Frynas, J.G. \& Scola, A. (2017) "Integration of Nonmarket and Market Activities in Cross-border Mergers and Acquisitions", British Journal of Management, vol. 28, no. 4: 629-648

Blonigen, B. \& Piger, J. (2014) "Determinants of foreign direct investment", Canadian Journal of Economics, vol. 47, no. 3: 775-812

Boateng, A., Qian, W. \& Tianle, Y. (2008) "Cross-border M\&As by Chinese firms: An analysis of strategic motives and performance", Thunderbird International Business Review, vol. 50, no. 4: 259-270

Brouthers, K.D. \& Dikova, D. (2010) "Acquisitions and Real Options: the Greenfield Alternative", Journal of Management Studies, vol. 47, no. 6: 1048-1071

Calderón, C., Loayza, N. \& Servén, L. (2004) “Greenfield Foreign Direct Investment and mergers and acquisitions: Feedback and macroeconomic effects", World Bank Group, available online at https://openknowledge.worldbank.org/ handle/10986/13941, (on-line access: February $20^{\text {th }}, 2018$ )

Chari, A., Ouimet, P. \& Tesar L. (2010) "The value of control in emerging markets", The Review of Financial Studies, vol. 23, no. 4: 1741-1770

Danakol, S., Estrin S., Reynolds, P. \& Weitzel, U. (2017) "Foreign direct investment via M\&A and domestic entrepreneurship: blessing or curse?", Small Business Economics, vol. 48, no. 3: 599-612

Dike, C. (2018) "Effects of Foreign Direct Investment in Sub-Saharan Africa economic growth: evidence from panel data analysis", International Journal of Economics and Financial Issues, Econjournals, vol. 8, no. 2: 255-261

Erel, I., Liao, R. \& Weisbach, M. (2012) "Determinants of cross-border mergers and acquisitions", The Journal of Finance, vol. 67, no. 3: 1045-1082

European Commission (2017) Mergers cases http://ec.europa.eu/competition/ elojade/isef/index.cfm?clear=1\&policy_area_id=2 [on-line access: March $1^{\text {st }}$ 2018]

European Commission (2004) Council Regulation (EC) No 139/2004 of 20 January 2004 on the control of concentrations between undertakings, published in the Official Journal of the European Union no. 24/29.01.2004, pages 1-21

Eurostat (2008) NACE Rev.2. Statistical Classification of economic activities in the European Community http://ec.europa.eu/eurostat/documents/3859598/ 5902521/KS-RA-07-015-EN.PDF [On-line access: February $2^{\text {nd }} 2018$ ]

Feito-Ruiz, I. \& Menéndez-Requejo, S. (2011) "Cross-border Mergers and Acquisitions in different legal environments", International Review of Law and Economics, vol. 31: 169-187

Fosfuri, A., Motta, M. \& Rønde, T. (2001) "Foreign Direct Investment and spillovers through workers' mobility”, Journal of International Economics, vol. 53, no. 1: 205-222

$\mathrm{Fu}, \mathrm{X}$. (2012) "Foreign Direct Investment and managerial knowledge spillovers through the diffusion of management practices", Journal of Management Studies, vol. 49, no. 5: 970-999 
Girma, S., Gong, Y., Görg, H. \& Lancheros, S. (2015) "Estimating direct and indirect effects of foreign direct investment on firm productivity in the presence of interactions between firms", Journal of International Economics, vol. 95, no. 1: 157-169

Hennart, J.-F. \& Reddy, S. (1997) "The choice between mergers/acquisitions and joint ventures: The case of Japanese investors in the United States", Strategic Management Journal, vol. 18: 1-12

Institute of Mergers, Acquisitions and Alliances (2017) Number and value of $M \& A$ in Europe, https://imaa-institute.org/mergers-and-acquisitions-statistics/, [On-line access February $15^{\text {th }}, 2018$ ]

Javorcik, B.S. (2004) "Does foreign direct investment increase the productivity of domestic firms? In search of spillovers through backward linkages", American Economic Review, vol. 94, no. 3: 605-627

Lebedev, S., Peng, M., Xie, E. \& Stevens, C. (2015) "Mergers and Acquisitions in and out of the emerging economies", Journal of World Business, vol. 50, no. 4: $651-662$

Lucas, R. (1990) "Why doesn't capital flow from rich to poor countries?", The American Economic Review, vol. 80, no. 2: $92-96$

Martynova, M. \& Renneboog, L. (2008) "Spillover of corporate governance standard in cross-border mergers and acquisitions", Journal of Corporate Finance, vol. 14: 200-223

Martynova, M. \& Renneboog, L. (2011) "The performance of the European market for corporate control: Evidence from the firth takeover wave", European Financial Management, vol. 17, no. 2: 208-259

Neto, P., Brandão, A. \& Cerqueira, A. (2009) "The Macroeconomic Determinants of Cross Border Mergers and Acquisitions and Greenfield Investments", available online at https://www.researchgate.net/publication/46466162 [On-line access: January $10^{\text {th }} 2018$ ]

Nocke, V. \& Yeaple, S. (2007) "Cross-border mergers and acquisitions vs. greenfield foreign direct investment: The role of firm heterogeneity", Journal of International Economics, vol. 72, no. 2: 336-365

Rabbiosi, Larissa, Elis, S. \& Bertoni, F. (2012) "Acquisitions by EMNCs in Developed Markets", Management International Review, vol. 52, no. 2: 193-212

Reuters (2018) Brexit at breaking point? Diary dates for Britain's EU departure, https://www.reuters.com/article/us-britain-eu-timeline/brexit-at-breakingpoint-diary-dates-for-britains-eu-departure-idUSKCN1M60PE [On-line access September $\left.26^{\text {th }} 2018\right]$

Shimizu, K., Hitt, M., Vaidyanath, D. \& Pisano, V. (2004) “Theoretical foundations of cross-border mergers and acquisitions: A review of current research and recommendations for the future", Journal of International Management, vol. 10: 307-353

Stepanok, I. (2015) "Cross-border mergers and greenfield foreign direct investment", Review of International Economics, vol. 23, no. 1: 111-136 
Stiebale, J. \& Reize, F. (2011) "The impact of the FDI through mergers and acquisitions on innovation in target firms", International Journal of Industrial Organization, vol. 29, no. 2: 155-167

UNCTAD (2018) World Investment Report. Investment and New Investment Policies, http://unctad.org/en/PublicationsLibrary/wir2018_en.pdf [on-line access May $28^{\text {th }} 2018$ ]

UNCTAD (2017) Global Investment Trend Monitor no. 25, February 2017, http://unctad.org/en/PublicationsLibrary/webdiaeia2017d1_en.pdf [on-line access January $15^{\text {th }} 2018$ ]

UNCTAD (2016) World Investment Report: Investor Nationality: Policy Challenges, http://unctad.org/en/PublicationsLibrary/wir2016_en.pdf [online access January $15^{\text {th }} 2018$ ]

UNCTAD (2015) World Investment Report: Reforming International Investment Governance, http://unctad.org/en/PublicationsLibrary/wir2015_en.pdf [online access February $\left.1^{\text {st }} 2018\right]$

UNCTAD (2014) World Investment Report: Investing in SDGs: An Action Plan, http://unctad.org/en/PublicationsLibrary/wir2014_en.pdf [on-line access January $21^{\text {st }} 2018$

UNCTAD (2000) World Investment Report: Cross-border Mergers and Acquisitions and Development, http://unctad.org/en/Docs/wir2000_en.pdf [on-line access: January $\left.20^{\text {th }} 2018\right]$

Višić, J. \& Škrabić Perić, B. (2011) "The determinants of value of incoming crossborder mergers \& acquisitions in European transition countries", Communist and Post-Communist Studies, vol. 44: 173-182

Wang, M. (2009) "Manufacturing FDI and economic growth: evidence from Asian economics", Journal Applied Economics, vol. 41, no. 8: 991-1002

Whitaker, S. (2016) Cross-border Mergers and Acquisitions, USA: John Wiley \&Sons, Inc.

World Bank (2017) Foreign Direct Investment, Net inflows (1970-2016) https://data.worldbank.org/indicator/BX.KLT.DINV.CD.WD [on-line access January $10^{\text {th }} 2018$ ]

Xie, E., Reddy, K.S. \& Liang, J. (2017) "Country-specific determinants of crossborder mergers and acquisitions: A comprehensive review and future research directions", Journal of World Business, vol. 52, no. 2: 127-183 